\title{
28. HEAT FLOW IN THE UPPER PART OF THE OCEANIC CRUST: SYNTHESIS OF IN-SITU TEMPERATURE MEASUREMENTS IN HOLE 504B ${ }^{1}$
}

\author{
Robert Gable, ${ }^{2}$ Roger Morin, ${ }^{3}$ Keir Becker ${ }^{4}$ and Philippe Pezard ${ }^{5}$
}

\begin{abstract}
A series of temperature logs was obtained from Hole 504B during Deep Sea Drilling Project (DSDP)/Ocean Drilling Program (ODP) Legs 69, 70, 83,92, and 111; Legs 137 and 140 provided additional opportunities to measure the temperatures in the hole five years after the thermal disturbance produced during Leg 111. The successive temperature profiles recorded over the seven-year time span between Leg 69 and Leg 111 depict a slow return to thermal equilibrium in the hole resulting principally from a gradually diminishing downward flow of cold ocean bottom water with time. Trend analysis and numerical simulations following the results of Leg 111 had forecast the gradual decay and perhaps complete cessation of downward flow by the time of Leg 137 in 1991. However, temperatures measured during Leg 137 revealed a remarkable renewal of downward flow into the hole at implied volumetric flow rates similar to those detected during Leg 83 some 10 years earlier. Moreover, the temperature log obtained during Leg 140 indicated much slower downward flows and, thus, a return to conditions approaching hydrostatic. These two latest temperature logs provide direct evidence of a highly transient and episodic hydrologic system that is contrary to previous conceptual models. Conductive heat flow in the deeper part of the hole is estimated from Leg 137 measurements to be $126.9 \pm 21$ $\mathrm{mW} / \mathrm{m}^{2}$, a value that is consistent with the Leg 111 heat-flow estimate of $120 \mathrm{~mW} / \mathrm{m}^{2}$ across the same interval. A systematic reduction in conductive heat flow with depth was observed in the hole during Leg 137, as it was during Leg 111. A detailed comparison of these two data sets spanning almost five years indicates that long-term, residual cooling of the formation may have resulted from earlier drilling into the lower part of the hole.
\end{abstract}

\section{INTRODUCTION}

Hole 504B is the deepest hole to penetrate the oceanic basement, passing through pillow lavas into the sheeted dike complex of a 5.9-m.y.-old oceanic crust. It was drilled to a maximum depth of 2000 meters below seafloor (mbsf) in 1991 during Leg 137, which was the continuation of a series of DSDP/ODP drilling and logging legs to this site (Legs 69, 70, 83, 92, and 111). Two additional legs have returned to Hole 504B since Leg 137 (Legs 140 and 148), and some complementary temperature measurements obtained during Leg 140 are included in this report.

Hole 504B is located in the eastern equatorial Pacific Ocean, approximately $200 \mathrm{~km}$ south of the spreading axis of the Costa Rica Rift. The crust is blanketed with about $275 \mathrm{~m}$ of low-permeability sediments composed essentially of ooze and clay. It had been postulated that this sedimentary cover effectively sealed the upper fractured oceanic crust and prevented mass exchange with ocean bottom water (Anderson and Hobart, 1976; Davis and Lister, 1977). However, when Hole 504B was first drilled (Leg 69), the measured temperatures in the upper part of the well $(0-300 \mathrm{~m})$ indicated a vigorous downward flow of cold bottom water that descended through the casing and invaded the upper levels of the basement (Becker et al., 1983a). The temperature profiles obtained during the legs that followed $(70,83,92$, and 111$)$ depicted the systematic stages of a gradual return to thermal equilibrium resulting from a diminishing downward flow of seawater over time (Becker et al., 1983b, 1985; Gable et al., 1989). The initial volumetric rate of downward flow into Hole 504B was estimated to be $6000-7000 \mathrm{l} / \mathrm{hr}$, decreasing to approximately 150-200 l/hr some 3.5 years later (Becker et al., 1983b, 1985). A trend analysis and numerical simulations (Williams et al., 1986) forecast

\footnotetext{
${ }^{1}$ Erzinger, J., Becker, K., Dick, H.J.B., and Stokking, L.B. (Eds.), 1995. Proc. ODP, Sci. Results, 137/140: College Station, TX (Ocean Drilling Program).

${ }_{3}^{2}$ Bureau de Recherches Géologiques et Minières, 45060 Orléans, France.

${ }^{3}$ United States Geological Survey, Denver, CO 80225 , U.S.A.

${ }^{4}$ University of Miami, Miami, FL 33149-1098, U.S.A.

${ }^{5}$ Institut Méditerranéan de Téchnologie, Téchnopole de Château-Gombert, 13451 Marseille Cedex 13, France.
}

the continued decay and perhaps complete cessation of downward flow by the time Leg 137 returned to this site in 1991.

Various stages in Hole 504B's return to thermal equilibrium are illustrated in the composite of temperature logs from Legs 69, 70, 83, 92, 111, and 137 (Fig. 1, adapted from Becker et al., 1985). Conductive heat flow across the lower part of the hole (823-1254 mbsf) as determined from Leg 111 data was $120.3 \pm 17 \mathrm{~mW} / \mathrm{m}^{2}$ (Gable et al., 1989). This estimate indicates a systematic reduction of measured heat flow with depth from approximately $196 \mathrm{~mW} / \mathrm{m}^{2}$ in the overlying sediments (measured in the adjacent Holes 504 and 504C during Leg 69) to $120 \mathrm{~mW} / \mathrm{m}^{2}$ in the basement at a depth of $1250 \mathrm{mbsf}$. Possible causes for this vertical reduction in heat flow have been examined (Gable et al., 1989; Fisher and Becker, 1991), but no adequate explanation has been provided.

\section{RESULTS}

\section{Temperature-logging Procedure}

The equipment used to obtain temperature and temperature-gradient profiles in Hole 504B during Legs 137 and 140 was essentially the same as that used to record temperatures during Leg 111. The temperature tool was run slowly downward from the seafloor to the bottom of the hole at a logging speed of $4 \mathrm{~m} / \mathrm{min}$ with a digitized recording interval of $10 \mathrm{~cm}$. Temperatures were measured continuously throughout the hole without the probe encountering any obstruction or touching down on the bottom. For technical and logistical reasons, fluid samplers were run to depths of 350 and $550 \mathrm{mbsf}$ prior to the deployment of the temperature tool during Leg 137. However, these activities did not appear to disturb the in-situ thermal conditions recorded a few hours later.

\section{Analysis of Temperature Data}

The temperature profile recorded during Leg 137 is presented in Figure 2. Low temperatures are observed extending from the seafloor to a depth of $310 \mathrm{mbsf}$. This distribution is quite similar to that obtained during Leg 70 after the hole had initially penetrated basement and a vigorous downward flow of seawater had been established 


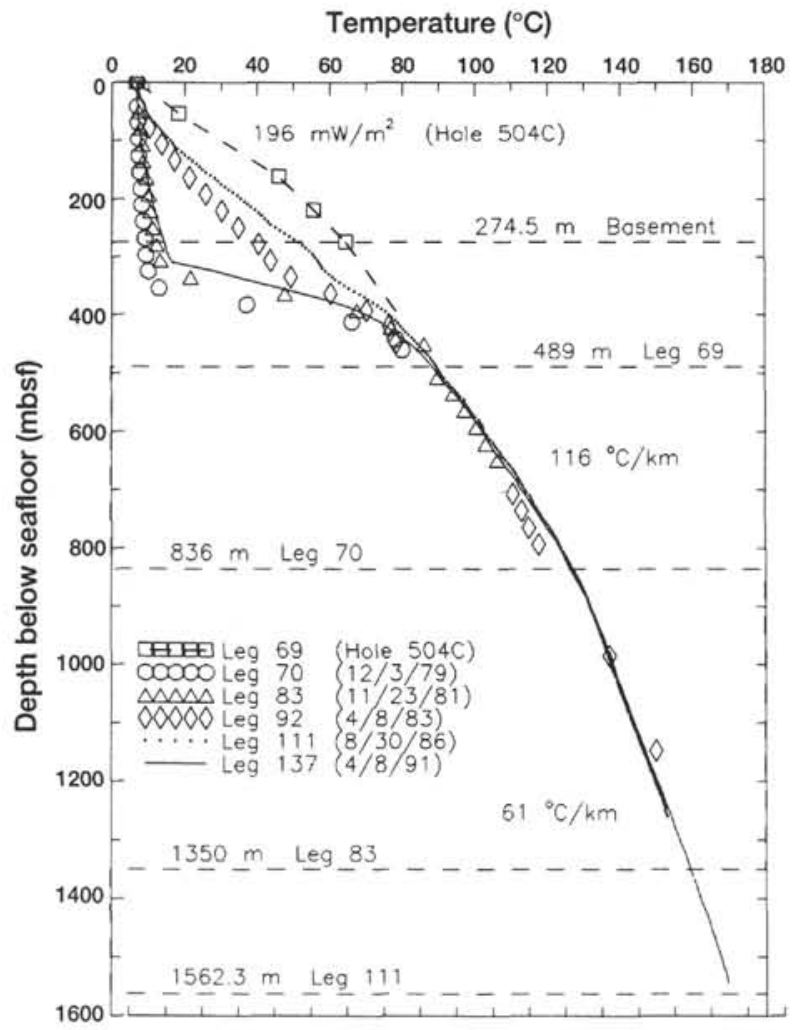

Figure 1. Composite of temperature logs measured in Hole 504B up to Leg 137 in 1991.

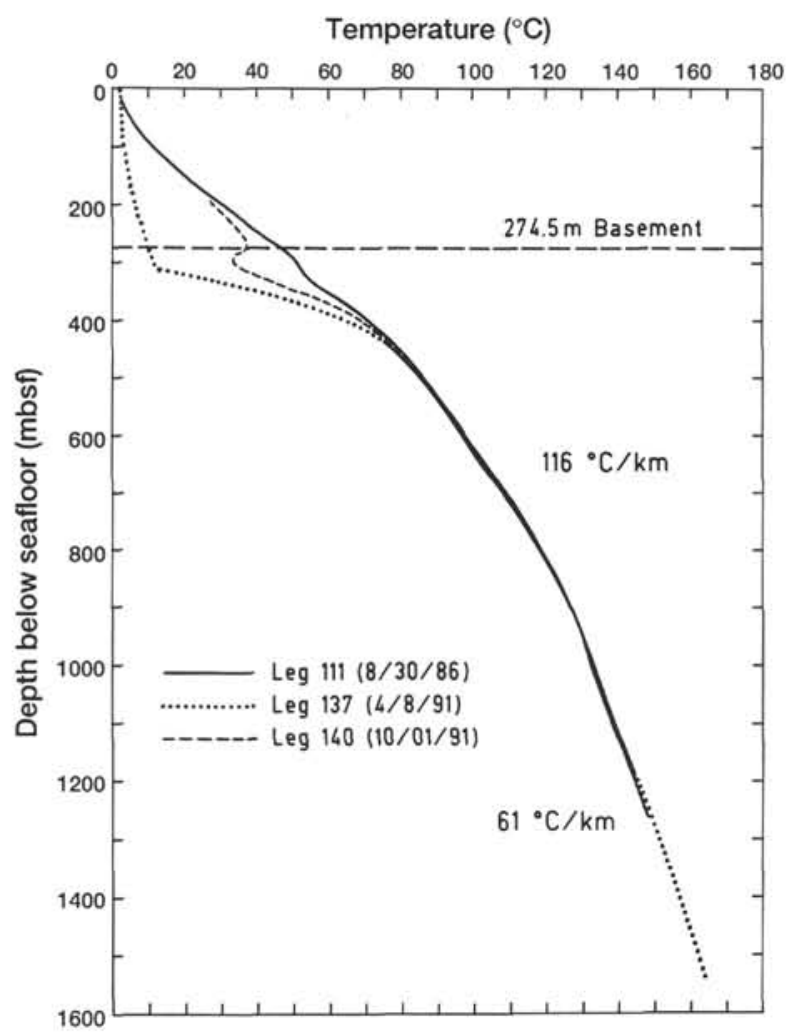

Figure 2. Temperature profiles measured in Hole 504B during ODP Legs 111, 137 , and 140 .

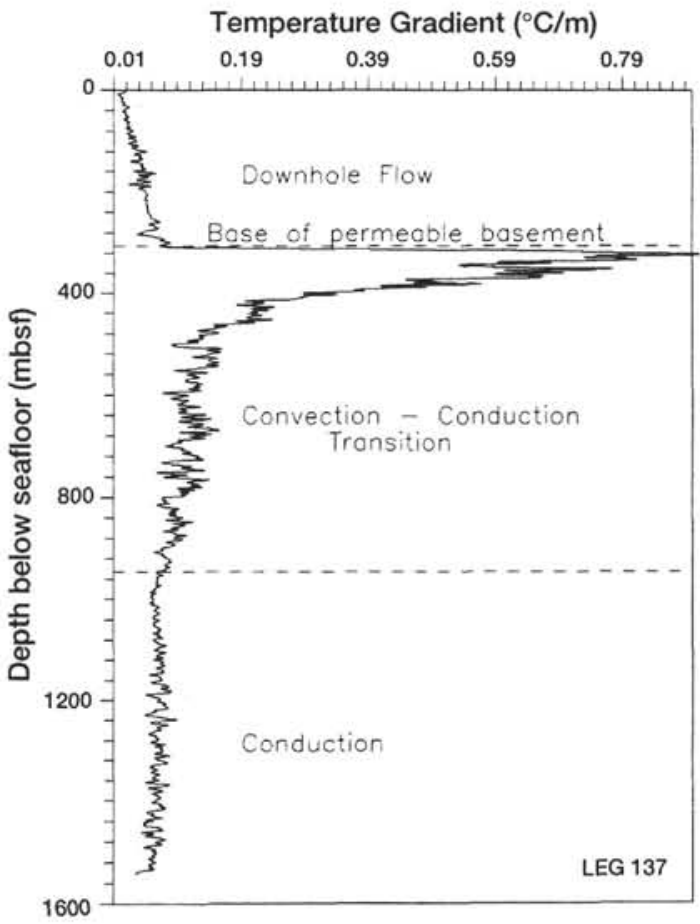

Figure 3. Temperature-gradient profile computed for Hole 504B from Leg 137 temperature log.

(Becker et al., 1983a, 1983b). Below 310 mbsf, temperatures display a rapid increase of more than $10^{\circ} \mathrm{C}$ over a $50-\mathrm{m}$ depth interval. Then, below 400 mbsf, temperatures closely follow the pattern recorded five years earlier during Leg 111 and depict a relatively stable thermal environment. The difference between Leg 137 temperatures and those of Leg 111 is less than $1^{\circ} \mathrm{C}$ down to the depth of $1000 \mathrm{mbsf}$, with the Leg 137 temperatures being consistently higher. This situation is indicative of a gradual return to thermal equilibrium following disturbances associated with drilling and circulation. The final temperature measured at 1545 mbsf, near total depth prior to Leg 137 drilling operations, was $164.08^{\circ} \mathrm{C}$.

During Leg 140, which occurred five months after Leg 137, a temperature log was obtained only down to a depth of roughly 500 mbsf before the onset of drilling activities; a second temperature log was recorded immediately after drilling. The first log is presented in Figure 2 , but the latter $\log$ was highly disturbed because of drilling and circulation and has not been included in this analysis. Inspection of the first temperature log from Leg 140 (Fig. 2) reveals that temperatures had recovered dramatically from the conditions observed during Leg 137 and once again approached values recorded during Leg 111. An anomalous temperature inversion across the narrow depth interval from 290 to $310 \mathrm{mbsf}$ sharply delineates a local permeable zone where the formation has been significantly cooled by cold bottom water and where recovery to thermal equilibrium has been correspondingly retarded.

The temperature-gradient profile for Hole 504B categorizes three distinct thermal regimes (Fig. 3):

1. An upper section $(0-480 \mathrm{mbsf})$ in which the thermal state is dominated by the convective effects of downward flow. From 0 to about $310 \mathrm{mbsf}$, the temperature gradient increases slowly as a result of heat transfer from the warmer surrounding sediments and basement through the casing. The sudden increase in gradient below 310 mbsf identifies the lower boundary of the permeable reservoir and a transition to the more thermally conductive zone down to $480 \mathrm{mbsf}$.

2. A middle section (480-900 mbsf) where moderate, small-scale variations in temperature gradient are superimposed upon a general 
decline in gradient with depth. This distribution is indicative of a transition to a predominantly conductive regime within the much less permeable pillow lavas below.

3. A lower section (900-1545 mbsf) characterized by a slightly decreasing temperature gradient and smaller fluctuations as a function of depth. This reduction in gradient is likely related to the gradual increase in the thermal conductivity of the dense sheeted dikes. The apparent correlation between temperature gradient and thermal conductivity is also indicative of a predominantly conductive heat transfer regime.

\section{Interpretation of the Geothermal State}

The thermal state of the upper section of the hole is dominated by the effects of downward flow of cold bottom water. The temperature distribution measured during Leg 137 is similar to that measured nearly 10 years earlier during Leg 83 (Fig. 1), and geochemical analyses of fluid samples collected from a depth of $350 \mathrm{mbsf}$ support the concept of a renewal of downward flow (Magenheim et al., 1992). The temperature data obtained during Leg 140 confirm the location of a permeable zone based on the interpretations of previous logs and provide further evidence of a relatively short-term episodic burst of fluid flow down Hole 504B. Previous temperature logs had only indicated a gradual and systematic decrease in flow with time.

Heat transfer in the deeper part of the hole (900-1545 mbsf) is predominantly conductive. Seventy-eight heat-flow estimates were computed for different depths below $853 \mathrm{mbsf}$ using thermal conductivity values determined aboard ship from recovered basalt samples (Karato et al., 1983; Becker et al., 1983b, 1985; Shipboard Scientific Party, 1988, pp. 93-104) and corresponding gradient values calculated from the Leg 137 temperature log. The average heat flow across the depth interval of $853-1515 \mathrm{mbsf}$ is $125.9 \pm 21 \mathrm{~mW} / \mathrm{m}^{2}$ (Fig. 4). This result is consistent with the heat-flow estimate of $120.3 \pm 17 \mathrm{~mW} / \mathrm{m}^{2}$ (Fig. 5) calculated earlier from the Leg 111 temperature log across the depth interval of 853-1254 mbsf (Gable et al., 1989). The lowermost section of the hole below 1420 mbsf shows a trend of decreasing heat flow as a function of depth, perhaps a remnant cooling effect produced by prior drilling and circulating activities during Leg 111 .

The polynomial fits of heat flow vs. depth presented in Figure 4 for Leg 137 and in Figure 5 for Leg 111 depict wave-like patterns that could be interpreted as the manifestation of convection cells within the borehole. However, similar wave-like profiles are also observed in the vertical distributions of thermal conductivity (Fig. 6). Although the fluctuations in thermal conductivity do not completely compensate for the inverse fluctuations in gradient, the fact that these two profiles behave in direct opposition is indicative of predominantly conductive heat transfer conditions.

\section{SUMMARY}

The shallow part of Hole 504B can be characterized as a convective heat transfer region. Downward flow of ocean bottom water has been identified in this hole since drilling was initiated in 1979. Based on the interpretation of subsequent temperature logs, this flow gradually diminished over the following seven years, and it was generally assumed that flow would eventually cease once subhydrostatic pressures within the fractured and permeable basement equilibrated. However, the Leg 137 temperature log revealed a completely unexpected renewal of downward flow to volumetric rates comparable to those seen 10 years earlier. Moreover, the Leg 140 temperature log indicated that most of this flow had stopped only a few months later, with conditions once again approaching hydrostatic. These last two temperature logs demonstrate a highly transient and episodic hydrologic system and give cause to reevaluate previous conceptual models of heat and mass transfer in this borehole.

The temperature-gradient profile for Hole 504B delineates three distinct thermal regimes over which an apparent vertical reduction in

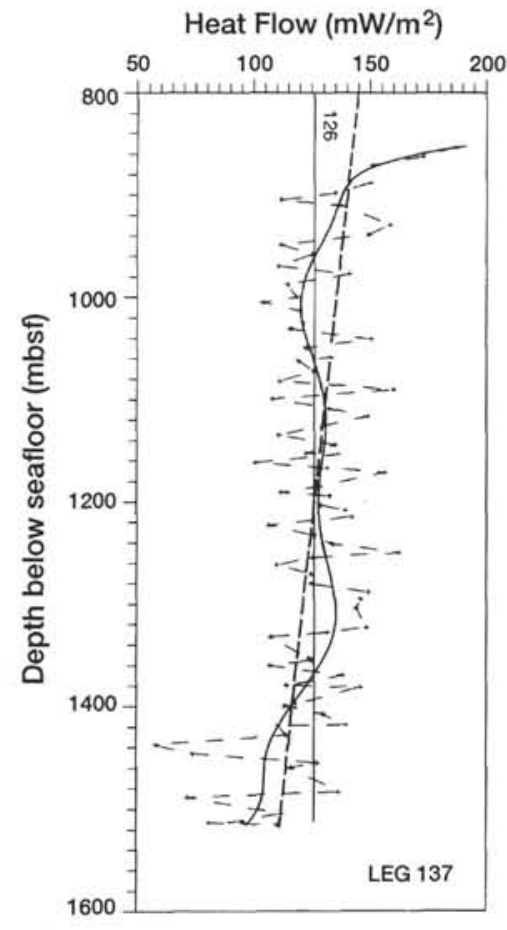

Figure 4. Plot of heat flow vs. depth in Hole 504B derived from Leg 137 temperature data, including discrete heat-flow values (asterisks), linear regression fit (dashed line), and polynomial fit (solid curved line).

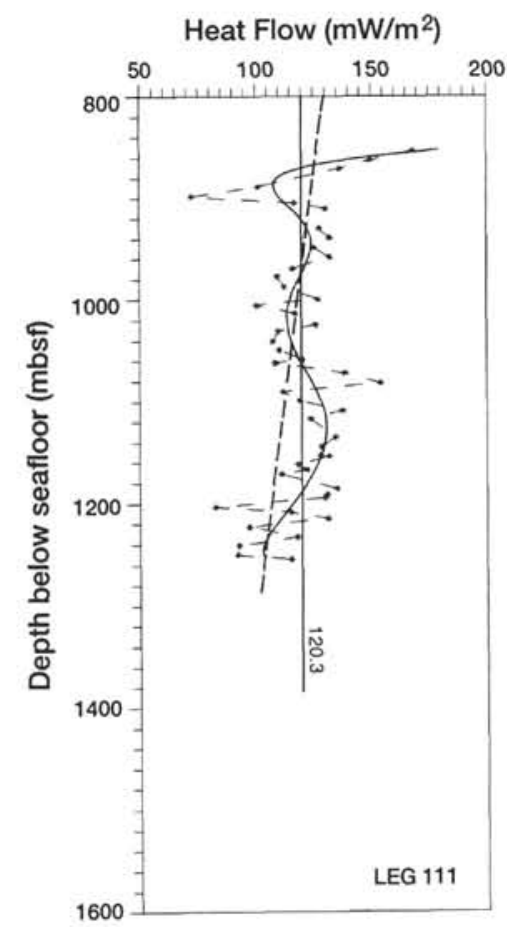

Figure 5. Plot of heat flow vs. depth in Hole 504B derived from Leg 111 temperature data, including discrete heat-flow values (asterisks), linear regression fit (dashed line), and polynomial fit (solid curved line). 


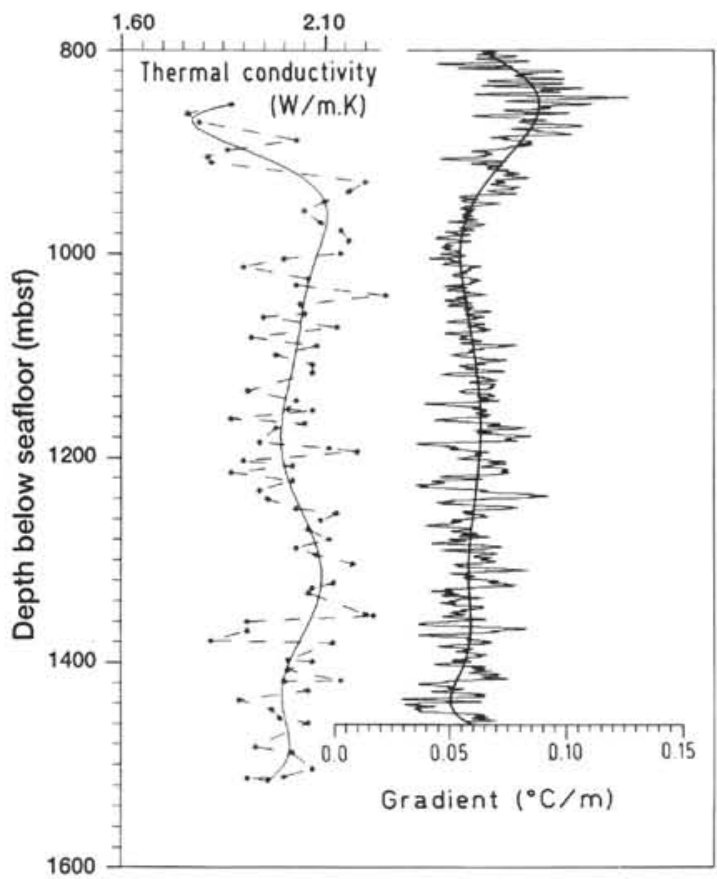

Figure 6. Plot of thermal conductivity determined from cores vs. depth in Hole 504B alongside plot of temperature gradient from Leg 137. Asterisks identify discrete values of thermal conductivity, and solid lines represent polynomial fits to the two data sets.

heat flow is observed. Heat flow ranges from about $200 \mathrm{~mW} / \mathrm{m}^{2}$ in the surficial sediments to about $126 \mathrm{~mW} / \mathrm{m}^{2}$ in the deeper part of the hole. Several possible causes for this decrease, including the likely existence of slow convection within the borehole, have been examined (Gable et al., 1989; Fisher and Becker, 1991), but no completely satisfactory explanations have been presented. The linear component of heat-flow reduction with depth in the hole below 850 mbsf was computed to be approximately $30 \mathrm{~mW} / \mathrm{m}^{2}$ per kilometer from Leg 111 temperature data and roughly $50 \mathrm{~mW} / \mathrm{m}^{2}$ per kilometer from the Leg 137 temperature log. The larger decrease associated with Leg 137 is perhaps due to a residual cooling effect in the lower part of the hole from Leg 111 drilling. If only the Leg 137 heat-flow values above the section drilled during Leg 111 are considered (i.e., across the depth interval used for Leg 111 heat-flow determinations), the rate of heatflow reduction with depth falls to approximately $21 \mathrm{~mW} / \mathrm{m}^{2}$ per kilometer. Thus, residual cooling due to past circulation and drilling activities may offer some explanation for the vertical decline in heat flow measured in this hole.

\section{REFERENCES*}

Anderson, R.N., and Hobart, M.A., 1976. The relation between heat flow, sediment thickness, and age in the Eastern Pacific. J. Geophys. Res., 81:2968-2989.

Becker, K., Langseth, M.G., and Von Herzen, R.P., 1983a. Deep crustal geothermal measurements, Hole 504B, Deep Sea Drilling Project Legs 69 and 70. In Cann, J.R., Langseth, M.G., Honnorez, J., Von Herzen, R.P., White, S.M., et al., Init. Repts. DSDP, 69: Washington (U.S. Govt. Printing Office), 223-236.

Becker, K., Langseth, M.G., Von Herzen, R.P., and Anderson, R.N., 1983b. Deep crustal geothermal measurements, Hole 504B, Costa Rica Rift. J. Geophys. Res., 88:3447-3457.

Becker, K., Langseth, M.G., Von Herzen, R.P., Anderson, R.N., and Hobart, M.A., 1985. Deep crustal geothermal measurements, Hole 504B, Deep Sea Drilling Project Legs 69, 70, 83, and 92. In Anderson, R.N., Honnorez, J., Becker, K., et al., Init. Repts. DSDP, 83: Washington (U.S. Govt. Printing Office), $405-418$.

Davis, E.E., and Lister, C.R.B., 1977. Heat flow measured over the northern Juan de Fuca Ridge: evidence for widespread hydrothermal circulation in a highly heat transportive crust. J. Geophys. Res., 82:4845-4860.

Fisher, A.T., and Becker, K., 1991. The reduction of measured heat flow with depth in DSDP Hole 504B: evidence for convection of borehole fluids? Sci. Drill., 2:34-40.

Gable, R., Morin, R.H., and Becker, K., 1989. Geothermal state of Hole 504B: ODP Leg 111 overview. In Becker, K., Sakai, H., et al., Proc. ODP, Sci. Results, 111: College Station, TX (Ocean Drilling Program), 87-96.

Karato, S., Wilkens, R.H., and Langseth, M.G., 1983. Shipboard physicalproperties measurements of basalts from the Costa Rica Rift, Deep Sea Drilling Project Legs 69 and 70. In Cann, J.R., Langseth, M.G., Honnorez, J., Von Herzen, R.P., White, S.M., et al., Init. Repts. DSDP, 69: Washington (U.S. Govt. Printing Office), 675-681.

Magenheim, A.J., Bayhurst, G., Alt, J.C., and Gieskes, J.M., 1992. ODP Leg 137, borehole fluid chemistry in Hole 504B. Geophys. Res. Lett., 19:521524.

Shipboard Scientific Party, 1988. Site 504: Costa Rica Rift. In Becker, K., Sakai, H., et al., Proc. ODP, Init. Repts., 111: College Station, TX (Ocean Drilling Program), 35-251.

Williams, C.F., Narasimhan, T.N., Anderson, R.N.,Zoback, M.D., and Becker, K., 1986. Convection in the oceanic crust: simulation of observations from Deep Sea Drilling Project Hole 504B, Costa Rica Rift. J. Geophys. Res., 91:4877-4889.

\footnotetext{
Abbreviations for names of organizations and publications in ODP reference lists follow the style given in Chemical Abstracts Service Source Index (published by American Chemical Society).
}

Date of initial receipt: 28 June 1993

Date of acceptance: 14 March 1994

Ms 137/140SR-036 